Physiologie de LA REPRODUCTION

PHYSIOLOGY OF REPRODUCTION

\title{
EFFET DE L'ACCOUPLEMENT ET DE L'INSÉMINATION ARTIFICIELLE SUR LE MOMENT DE L'OVULATION DE LA TRUIE
}

\author{
J.-P. SIGNORET, F. du MESNIL du BUISSON et P. MAULÉON \\ Station de Physiologie de la Reproduction, \\ Centre de Recherches de Tours, I. N.R. A., \\ Nouzilly, 37380 Monnaie
}

\section{RÉSUMÉ}

Le déroulement de l'ovulation a été observé chez 74 truies nullipares, par un examen coelioscopique des ovaires $30,35,4^{\circ}, 45,5^{\circ}$ heures après le début de l'œstrus. Il en a été de même chez 59 jeunes truies accouplées dès le début de la réceptivité, à nouveau 6 heures plus tard, chez 28 jeunes truies inséminées artificiellement et 37 soumises à une injection de $75^{\circ}$ UI de PMSG à la fin d'un traitement de synchronisation par le méthallibure.

L'accouplement avance le moment de l'ovulation ( $34 \mathrm{~h} 30$ contre $4^{\circ} \mathrm{h}$ après le début de l'œstrus) et en réduit la durée ( $\mathrm{r} h$ contre $3 \mathrm{~h}$ o8); par contre, l'insémination artificielle au même moment est sans effet. L'hypothèse d'une action sur la décharge des hormones gonadotropes hypophysaires est étayée par le fait qu'une injection de PMSG provoque de même un effet de racourcissement de la durée de l'ovulation.

\section{SUMMARY}

EFFECT OF MATING AND A.I. ON OVULATION TIME IN THE SOW

The moment and duration of ovulation was observed $3 \circ, 35,4 \circ, 45$ and 50 hours after the onset of cestrus by coelioscopy in 59 Large White gilts mated twice (at the first detection of cestrus and $6 \mathrm{~h}$ later), in 28 gilts artificially inseminated at the same moment, in 37 gilts treated with 750 IU PMSG at the end of methallibure synchronization of œstrus, and in 74 unmated and untreated controls. By probit analysis, the median time between the beginning of œstrus and the start of ovulation was found to be $34 . \mathrm{I} \mathrm{h}$ in mated females vs 38.0 in controls. In the two groups,

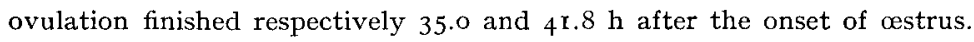


Thus the median time for the onset of ovulation was $3.9 \mathrm{~h}$ earlier and the duration $2.8 \mathrm{~h}$ shorter, in mated females, whereas artificial insemination was not effective in inducing earlier ovulation.

The effects of the stimuli associated with mating could be mediated by modifications in the patterns of discharge of pituitary gonadotropins, as a single injection of PMSG similarly reduces the duration of ovulation.

\title{
SYNCHRONISATION DES CHALEURS DES TRUIES NULLIPARES PAH UN TRAITEMENT MÉTHALLIBURE PMSG-HCG. EFFET DE MODIFICATION DES MOMENTS D'INJECTION
}

\author{
F. MARTINAT, J.-P. SIGNORET et F. du MESNIL du BUISSON, \\ Station de Physiologie de la Reproduction, \\ Centre de Recherches de Tours, I. N.R.A., \\ Nouzilly 37380 Monnaie
}

\section{RÉSUMÉ}

Des truies nullipares Large White ou hybride Landrace $\times$ Large White reçoivent $100 \mathrm{mg}$ par jour de méthallibure pendant 20 jours, puis I 000 UI de PMSG et 500 UI de HCG en injection intramusculaire.

Dans une première expérience ( 46 truies) PMSG a été injectée le $\mathrm{J}_{1}$ et HCG soit le $\mathrm{J}_{4}$, soit le $\mathrm{J}_{5}$. La réduction de l'intervalle entre l'injection de PMSG et celle de HCG a tendance à abaisser le taux de groupage des chaleurs $\left(5^{\circ} \mathrm{p}\right.$. Ioo contre $72,0 \mathrm{p}$. I0o), le taux de mise bas $(66,6 \mathrm{p}$. Iо० contre $8 \mathrm{I}, 3$ p. IOO) et la prolificité $(7,9$ contre 9,4$)$.

Dans une deuxième expérience (25 truies) PMSG et HCG ont été injectées à 4 jours d'intervalle soit le $J_{1}$ et le $J_{5}$, soit le $J_{2}$ et le $J_{6}$.

En retardant le moment des injections, on ne constate aucun effet bénéfique.

\section{SUMMARY}

\section{HEAT SYNCHRONIZATION OF NULLIPAROUS SOWS BY A METHALIIBURE} AND PMSG-HCG TREATMENT ; EFFECT OF CHANGING THE MOMENTS OF INJECTION

Nulliparous Large White sows or Landrace $\times$ Large White hybrid sows received $100 \mathrm{mg} /$ day of methallibure during 20 days followed by intramuscular injections od I ooo IU PMSG and 5 Oo IU HCG.

In the first trial (46 sows) PMSG was injected on day I $\left(D_{1}\right)$ and HCG either on $D_{4}$ or $D_{5}$. Reduction of the interval between injection of PMSG and that of HCG tended to lower the rate of heat blocking ( $5 \circ \mathrm{p}$. Ioo versus $72.0 \mathrm{p}$. Ioo), the farrowing rate and the prolificacy. 